DOI https://doi.org/10.30525/978-9934-26-073-5-1-73

\title{
CONCEPTION OF VIOLET IN UKRAINIAN AND ENGLISH LINGUOCULTURES
}

\author{
Cherniavska A. V. \\ Ph.D. Student at the Germanic Languages \\ and Translation Studies Department \\ Drohobych Ivan Franko State Pedagogical University \\ Drohobych, Lviv region, Ukraine
}

Any idiolect is to be not only correct but also vivid and expressively abundant. This depends on the appropriate use of phraseologisms with their uniqueness, encipherment, play on sounds, expressivity of metaphors. The knowledge of a set expression's «biography» is supposed to be effective in determining its content mode and use relevance [15, p. 45].

According to «Oxford Advanced Learner's Dictionary» the lexeme violet is defined as: «a small wild or garden plant, usu with sweet-smelling purple or white flowers» [2, p. 1329]. Thus, the floronym violet represents a small sweet-smelling flower of a purple colour as well as the colour name violet / violet-coloured [7, p. 638] which is used for the signification of a lilac, bluishpurple colour. The definition of the lexeme фіалка is as such in Ukrainian: «трав'яниста рослина родини фіалкових із фіолетовими, рідше жовтими, білими або різноколірними квітками» [14]. Accordingly, the colour name фіялковий [9, p. 439] is used as a manifestation of violet or lilac colours.

The English phraseo-term, inherent in the botany domain, violet family [7, p. 638] signifies the plants of Genus Viola, family Violaceae, and in colloquial speech violets [7, p. 638], literally mean «cabbage» in the USA, and «onion» in GB.

In the English linguoculture, the floronym violet can be associated with a timid, submissive and shy person who enjoys a solitary life, like in the stereotyped comparison: meek as a violet [6, p. 448]. The concept lack of selfassertiveness is objectivised in the idiom $-a$ shrinking violet $[1, \mathrm{p} .368]$. The phraseologism to play the shrinking violet [7, p. 638] means «to pretend to be innocent». The researched floronym explicates the seme «shyness / modesty / innocence.» Such meaning of the floronym фіалка is not appropriate of the Ukrainian language.

The Ukrainians say: Фія-фіялочка, яка мати, така й дочка [13, p. 113] with reference to the beauty of a young and attractive mother and daughter. 
The analysed floronym has the semes «beauty / youth» and its semantic constituents contribute to phraseological objectivation of the concept similarity.

The English proverbialized expression (the term coined by Z. Kotsiuba [10, p. 57]: To throw perfume on the violet [4, p. 187], which is attributed to W. Shakespeare, verbalises a useless activity, since a violet has its natural scent, so it is vain to sprinkle it with perfume. The floronym violet's semantics contains the seme «fragrance.» The seme «pleasant smell» of the analysed floronym is realised within the boundaries of the American vulgar slangy expression come up (or out) smelling of roses (or violets) [5, p. 268], which means «to avoid punishment; to be let off» though, the floronym violet serves as a variable element in this context. The complete version of this proverb is: he could fall into shit and come up smelling of violets [6, p. 223], it deals with a notion of a lucky person. The binary opposition «fragrance - stink» is actualized in this context, and the semantic components of the researched floronym serve as a part of the opposition as well as contribute to phraseological objectivation of the concept luck.

A great number of proverbial items with the reference words баба-дid (granny - granddad) are of a longstanding origin. Expressions that come from legend fragments, fairy tales, anecdotes, and popular beliefs belong here. This range was enriched due to the expressions, coloured with juicy folk humour with figurative meaning: «Дід про хліб, а баба про фіялки» [13, p. 14]. There exist a variety of adversative puns with the floronym фіалка in the Ukrainian folklore, namely: Дід про хліб, баба про фіялки [13, p. 150]; Дідови хліб, а бабі фіялки [13, р. 150]; Дід о хлібі, а баба о фіялках [13, р. 149]; Дід о хлібі, а баба о хвіялках [16, p. 573]. The binary oppositions «man - woman» and «realism - idealism» concerning the contrast between a male and female mode of thinking is realized in the listed adages. The analysed floronym has a semantic component «something unimportant / minor», which serves as a basis for verbalization of the above mentioned oppositions. Though, there is such and idiom in the Ukrainian phraseology, as: фіалки в голові [12, p. 345], according to Z.Matsiuk, people use it with reference to «an unwise man». The researched floronym contains the semes «nonsense,» «stupidity.»

American linguoculture is characterised by the symbolical meaning of the floronym wood violet [3] (лісова фіалка), since this plant is the floral symbol of the state Wisconsin. Purple Violet [3] is the symbol of the state New Jersey, and a native violet (Viola papilionacea Lat.) / also meadow violet [3] (фіалкамотильковидна) serves as the flower emblem of the state Illinois. Floral symbolism for the signification of administrative-territorial units is not an integral element in the Ukrainian culture. 
In the world culture the violet flower denoted hidden advantages, beauty, and modesty. It symbolizes humility and, especially, that of Christ as the Son of God, and the white violet is the emblem of the Virgin Mary [11, p. 348]. The violet was a sign of the nature's awakening and the emblem of Athens at the same time. The Hellenes considered it to be the flower of grief and death. The deathbeds and graves of untimely deceased young girls were decorated with violets. Numerous European nations reckoned the violet as the emblem of purity, defencelessness, chastity, loyalty, devotion to the beloved knight, which was repeatedly eulogized by poets [8, p. 823].

Conclusions. The floronyms фіалка / violet meanings have such similar semantic components: «beauty,» «modesty,» «hidden advantages.» In Christianity the analysed floronym symbolises humility and is the emblem of the Virgin Mary. Such semantic components of the floronym violet as: «a timid, submissive, shy person,» «luck,» and «fragrance,» the latter constitutes a part of the binary opposition «fragrance - stink,» are inherent of the English phraseology solely. In the American linguoculture the researched floronym constitutes a floral symbol representing several states. Such semes of the floronym фіалка as: «youth,» «smth unimportant, minor,» «foolishness, nonsense» are appropriate of the Ukrainian phraseology. Moreover, the researched floronym's semantic components serve as a basis for the concept similarity actualization as well as binary oppositions «realism - idealism,» «man - woman» realization. Phraseological verbalization of other floronyms and peculiarities of their semantics are to be prospected in the analysed languages.

\section{References:}

1. Longman Idioms Dictionary. Edinburgh: Longman, 1998. 398 p.

2. Oxford Advanced Learner's Dictionary of Current English. 5th ed. / Ed. by J. Crowther. Oxford: Oxford Univ. Press, 1995. 1428 p.

3. State Symbols USA. URL: https://statesymbolsusa.org/ categories/flower

4. The Facts on File Dictionary of Allusions / by Martin H. Manser. New York, 2009. 532p.

5. The Oxford Dictionary of Idioms. 2nd ed. / Ed. by J. Siefring. Oxford: Oxford University Press, 2004. 352 p.

6. Thesaurus of traditional English metaphors. 2nd ed. / P. Wilkinson. London: Routledge, Taylor \& Francis e-Library, 2006. 2009 p.

7. Англо-український словник: у 2 т. Близько 120000 слів / уклав М. Балла. Київ : Освіта, 1996. Т. 2. 712 с. 
8. Енциклопедичний словник символів культури України / за заг. ред. В.П. Коцура, О.І. Потапенка, В.В. Куйбіди. 5-е вид. КорсуньШевченківський: ФОП Гавришенко В.М., 2015. 912 с.

9. Караванський С. Практичний словник синонімів української мови. Київ : «Українська книга», 2000. 480 с.

10. Коцюба З.Г. Рефлексія побутової свідомості в різномовному провербіальному просторі (від універсального до національного) : монографія. Львів : ДП «Видавничий дім «Укрпол», 2010. 472 с.

11. Купер Дж. Энциклопедия символов. Серия «Символы». Кн. IV. Москва: Ассоциация духовного единения «Золотой Век», 1995. 411 с.

12. Мацюк 3. Що сільце, то нове слівце: словник фразеологізмів Західного Полісся. Луцьк : Вежа-Друк, 2013. 476 с.

13. Прислів'я та приказки: Людина. Родинне життя. Риси характеру. упоряд. М. М. Пазяк. Київ: Наукова думка, 1990. 528 с.

14. Словник української мови. Академічний тлумачний словник (1970-1980). URL: http://sum.in.ua

15. Ужченко В.Д. Народження і життя фразеологізму. Київ: Рад.шк., 1988. $279 \mathrm{c}$.

16. Українські приказки, прислів'я і таке інше. Уклав М. Номис / Упоряд., приміт. та вступна ст. М. М. Пазяка. Київ: Либідь, 1993. 768 с.

DOI https://doi.org/10.30525/978-9934-26-073-5-1-74

\title{
VERBALIZATION OF COSMOLOGY IN THE CONCEPTUAL SYSTEM OF UKRAINIAN AND FRENCH-SPEAKING BELGIAN SYMBOLIST POETRY
}

\author{
Chystiak D. 0. \\ Doctor of Philological Sciences, \\ Associate Professor at the Department of Romanic Philology \\ Institute of Philology \\ Taras Shevchenko National University of Kyiv \\ Kyiv, Ukraine
}

This research is devoted to the cosmological conceptual system, verbalized in Ukrainian and Belgian Symbolist poetry already analyzed in our previous works $[1 ; 2 ; 3]$. The poetic vocabulary of both national traditions reflects basic ideas and images of mythical cosmogony, structure of space and time, anthropomorphic, zoomorphic and other personifications of the universe and 274 